\title{
Embedded Socio-Legal Activism in China: The Case of Yirenping
}

\author{
Fu Hualing*
}

\section{Introduction}

Socio-legal activism led by lawyers and others can be interpreted as an effort by actors outside of the state apparatus to limit and resist state power and to force the state into a constitutional compromise. Chinese activism takes place in an increasingly pluralistic society, where the ruling Communist Party (Party) tolerates or even welcomes a certain degree of interest articulation and rights advocacy. Different social groups have taken different political stances and adapted different tactics in mobilizing law to fight for their rights and interests, and they have met with different degrees of success.

Socio-legal activism abounds in China, but why are some organizations and campaigns more successful than others? This paper discusses factors that lead to successful sociolegal activism in China and its potential pitfall. This paper offers a case study of the legal and political mobilization against health-based discrimination by the Beijing Yirenping Centre (北京益仁平中心, hereafter 'Yirenping') ${ }^{1}$ and its Internet portal, Gandan Xiangzhao (肝胆相照, hereafter 'HBV FORUM'). ${ }^{2}$ Yirenping is an anti-discriminatory NGO that is based in mainland China and dedicated primarily to the legal protection and promotion of rights of people who carry the Hepatitis B virus (HBV) while HBV FORUM is an Internet portal created in 2001 to highlight, and sensitize the general public to, the prevalent discrimination against HBV carriers in China. ${ }^{3}$ In 2006, organizers of HBV FORUM registered as a company called 'Yirenping', to carry out offline projects in promoting the rights of HBV carriers.

Yirenping is one of the most successful civil society organizations in China in the past ten years in launching public interest litigation. Through its litigation and social mobilization, Yirenping has been a strong civic force in promoting legal and policy changes against Hepatitis B-related discrimination. It has been successful in comparison with the socalled 'mass organizations', the state-led social service organizations such as the women's associations or associations for disabled persons. It has also out-performed the other grassroots civil society organizations, such as women's groups, AIDS/HIV groups and NGOs working in other fields. How is it that HBV carriers have their own independent organizations but others, such as sex workers, drug addicts, or pneumoconiosis patients could not? How does Yirenping survive in the hostile environment when other equally prominent rights advocacy NGOs suffered severe setbacks one after another, including Xu Zhiyong’s (许志永) Gongmeng (公盟), ${ }^{4}$ Wan 
Yanhai's (万延海) Aizhixing (爱知行) or Guo Jianmei’s (郭建梅) Center for Women's Law Studies \& Legal Services (妇女法律研究与服务中心) ? ${ }^{5}$

This case study explores the strength of HBV FORUM and Yirenping and the mutually reinforcing process in which online mobilization and offline actions interact to empower one particular group of vulnerable people in the Chinese society. ${ }^{6}$ From litigation on individual cases to social mobilization participation, Yirenping has resorted to a wide range of activities to challenge discriminatory law and practices. Over a decade, ten per cent of the Chinese witnessed a fundamental change in law and policy, and significant changes in practice, in relation to the treatment of HBV carriers in China. When Yiernping was first created, discrimination against HBV carriers was commonly practiced in workplaces and education sectors including kindergartens, and the discriminative practice was legally sanctioned. With the persistent fight of the HBV carriers and the great effort of Yirenping, by 2010, all the legal barriers to employment and education were effectively removed.

This paper makes a two-fold argument. First, in response to scandals and crisis, law offers remedies through the creation of new rights or better enforcement of existing rights. Legal remedy, while slow in pace and limited in scope, provides an institutional channel for disputes resolution and, in some circumstances, is able to bring the run-away cases from streets back to courts. The evolving legal reform in China continues to lure disputes and conflicts to a legal resolution, and there are push and pull factors that channel disputes into the judicial process. ${ }^{7}$ The Party/state has been adaptive in responding to crisis and innovative in designing new mechanisms. Institutional innovation in the past decade includes reform in budgetary process, government procurement, auditing, open government information, public hearing, consultation, Eparticipation, democracy, public interest litigation environmental cases, and collective bargaining in labor disputes. State polices are able to response to societal demands, and the social forces do engage with state policies.

Second, Yirenping's legal activism is embedded in China's social and legal systems. Embeddedness refers to the enmeshment of individuals or groups in social networks, manifested in direct or indirect individual and organizational relations between the individuals or groups and the larger society. Additionally, socio-legal activism is constrained by the social networks they are enmeshed in bureaucratically, instrumentally and effectively. Studies on Chinese lawyers have clearly demonstrated that politically embedded lawyers differ significantly from their unembedded counterparts in their political orientation, their understanding of rights and justice, and their relations with status quo. ${ }^{8}$ Socio-legal actors are also socially embedded, and their success or failure to mobilize social-legal action depends on the resourcefulness and quality of the community which they try to represent. Groups or individuals who are socially embedded tend to be more moderate in making their claims.

\section{From Online Networking to Offline Activism}

In the middle of 2011, China's Internet users reached 485 million and microblog users 
numbered 195 million. ${ }^{9}$ Compared with mature democracies, Chinese netizens use online discussion forums more often, and China has 'a more vibrant BBS culture. ${ }^{10}$ In a society well-known for its state ownership of mass media, restriction on information flow and government censorship, the Internet and other information technology facilitate access to information, horizontal communication and freedom of expression. Over the years since the inception of the Internet in China, Chinese netizens have nurtured and developed a culture of cyberactivism in which ordinary people use the Internet to expose scandals, monitor government officials and promote social justice. There is a strong belief that the Internet is a high impact-low cost weapon of the weak and is used as such.

It was in this particular backdrop of Internet empowerment that the anti-discrimination movement was born. HBV FORUM was created in September 2001 to provide information services and social networking for HBV carriers in China. HBV FORUM was predominantly a social online forum in nature and it was used mainly for the purpose of social networking for people living with HBV. The two most important functions of HBV FORUM, according to Lu Jun (陆军), the former chief coordinator of Yirenping, were information-sharing on $\mathrm{HBV}$ medicine and treatment and social networking including online dating.

HBV is endemic in China with an estimate of 130 million people living with this virus. $\mathrm{HBV}$ is an infectious disease of the liver caused by the HBV, which is transmitted human to human, through the exchange of body fluids, with the transmission from mother to child being the primary method. Discriminatory laws and policies existed as early as $1981,{ }^{11}$ but were not put into implementation until after the Hepatitis A virus breakout in Shanghai in 1988. There had been a wide range of discriminatory legal provisions. The most important of them was the 1994 Ministry of Personnel rules which required civil service applicants to undergo a medical test including hepatitis test. ${ }^{12}$ There were also special prohibitions: A State Council Regulation of 1987 banned all hepatitis virus carriers from holding service occupations in public places; ${ }^{13}$ and the Food Hygiene Law of 1995 banned hepatitis virus carriers from food processing industry. ${ }^{14}$ Although the Ministry of Health later on stated clearly that people living with hepatitis virus 'may be employed' if 'acute hepatitis is cured for one year and persistent hepatitis is cured for two years', 15 local government and the private sectors responded by continuous banning of all hepatitis virus carriers from employment. Before the recent legislative and policy changes, people living with HBV in China were subject to systematic employment discrimination. National laws and regulations largely failed to distinguish Hepatitis B from the more infectious Hepatitis A, and local rules were blatant in giving public and private employers carte blanche to test applicants for HBV and disqualify those who test HBV-positive. In medical terms, job applicants were required to undergo a 'two and a half pair' HBV test, and those with HBV surface antigen would be refused employment.

Living with fear, one principal concern for HBV carriers had been treatment and recovery and a normal social life without discrimination and the fear allowed pharmaceutical companies to exploit the issues by peddling their medicines and cures, often exaggerating the contagiousness and seriousness of the virus. The companies advertised their treatment and medicine with endorsement of celebrities and authorities. Throughout the 1990s, and 
to a lesser degree now, the market was full of conflicting, misleading, and fraudulent advertisements offering a variety of medical treatment to cure HBV. The abusive advertisements created a panic in society about HBV, and people living with HBV were often not in a position to make a sound judgment. Regulatory agencies and hospitals generally failed to provide the necessary information and services to correct this market failure. On the contrary, hospitals use the opportunities to profit by offering medical check-ups on HBVs. The discriminatory policies, compounded by false and unregulated medical advertisements for treatment of HBV, generated a culture of fear, which in turn reinforced discrimination. ${ }^{16}$

HBV FORUM filled the gap created by this market failure and government failure by providing a much needed alternative platform for puzzled and frustrated HBV carriers. HBV FORUM has two advantages. First, it is a specialist forum in which experienced carriers share their experiences and give advice on medical and social issues relating to HBV. ${ }^{17}$ Advice seeking and information sharing, on anonymous basis, remain core components of the online activities through which people suffering from the same disease and sharing a common interest provide mutual support. Second, the HBV Forum promotes a collective identity and creates a virtual community of people living with HBV. Participants in the HBV Forum share a common identity and encounter common problems in life. Facing fear and hostility in the real world, people living with HBV seek comfort and gain strength in the virtual world. The sharp contrast between online mutual support and offline discrimination contributes significantly to HBV FORUM's immense popularity: In 2003, the HBV Forum only had about 10,000 members, but membership reached 400,000 eight years later in 2010. ${ }^{18}$ In sum, the HBV Forum serves as a home to take care of the welfare of people living with HBV and a community in which members' identity, interest and position are amplified and sharpened.

Apart from discussion of HBV-related issues, with the encouragement of HBV FORUM organizers, people living with HBV also organize frequent social gatherings, such as camping and dinner parties. Gradually, voluntary offline events became routine and attracted an increasingly large group of people to the community. These social functions also allowed the development of a close-knit community in which members are united by their common identity - they refer to each other as comrades-in-arms (zhanyou, 战友). The offline activities provide a fertile ground for civic participation and civil society formulation. The offline activities would be reported online at HBV FORUM, to be discussed and reflected upon, providing additional incentives to continue and improve the offline activities. The online discussion also creates opportunities for horizontal, crossregional dialogue and support. Local HBV groups in different places upload photos of their gatherings and others activities, as well as their essays and poems onto HBV FORUM to share with other members.

Given the stereotyping and social isolation of people living with HBV, the HBV FORUM provides a special service for young people that would not be available otherwise dating. The HBV FORUM was predominately used by young people and that was especially the case in the first few years of its establishment. During that time, there was a self-selecting process in the HBV FORUM through which young, educated and 
relatively well-off men and women logged on with a clear intention of dating and socializing. Many of them 'met' in HBV FORUM, dated and got married, and remain committed to the HBV FORUM and their common cause thereafter.

HBV FORUM gained popularity in 2003 due to two high profile cases which changed government policies and reinforced solidarity within the HBV community. In April 2003, a university graduate Zhou Yichao (周一超) shocked the conscience of the nation and changed the lives of people living with HBV. Zhou applied to be a civil servant in Jiaxing city in Zhejiang province. He passed the entrance examination but was disqualified because he tested HBV-positive. In retaliation, Zhou stabbed to death a local government official and wounded another, and received the death sentence after trial as a result. ${ }^{19}$ Zhou's radical act and the subsequent trial generated immense publicity about the suffering of people living with HBV and discussion about the morality and legality of the discriminatory law and practice. Both the government and the society responded positively.

In the same year, China witnessed the first, high profile anti-discrimination lawsuit launched by a HBV carrier, with the assistance of HBV FORUM. Zhang Xianzhu (張先 著), a college graduate, applied for a civil servant post in Wuhui city in Anhui province. ${ }^{20}$ He passed the entrance test as a top candidate but was denied the opportunity because he was tested HBV-positive. Frustrated, Zhang surfed on the Internet and found HBV FORUM. He posted his story on HBV FORUM and caused a lively debate on his case. With the support from his comrades-in-arms in HBV FORUM and the pro bono legal service by Professor Zhou Wei (周伟) from the Sichuan University Law School, Zhang Xianzhu filed a case against the Wuhui City Personnel Bureau on 10 November 2003. ${ }^{21}$

News about the court's acceptance of this case was widely reported in the media and this case was regarded as 'The First Case of Hepatitis B Discrimination in China'. ${ }^{22}$ When the trial took place on 19 December 2003 in the Xinwu District Court of Wuhui City, more than 200 people, including journalists, attended the trial. ${ }^{23}$ While the court rejected the plaintiff's constitutional argument of equal protection of rights, the court found for the plaintiff on a more technical ground. ${ }^{24}$

The cases of Zhou Yichao and Zhang Xianzhu mobilized HBV carriers who, with the coordination of HBV FORUM, initiated a public campaign against HB-discrimination. Immediately after the filing of Zhang's case, 1,611 citizens signed and submitted an open letter to the Standing Committee of the National People's Congress and a range of legislative and policy bodies, calling for the removal of the prohibition of HBV carriers from joining the civil service. ${ }^{25}$

The campaign worked in the relatively open circumstances in 2003. In response to public exposure and public pressure that the case may have generated, provincial governments in Zhejiang, Sichuan, Fujian and Guangzhou took their own initiatives to amend their civil servant recruitment rules by lifting the bar on HBV carriers. ${ }^{26}$ On 19 January 2005, the State Council issued a new Common Standard of Medical Examination in Civil Servant Recruitment (Trial), under which people tested HBV-positive without having 
hepatitis are no longer prohibited from joining the civil service in China. ${ }^{27}$ In 2007 , the Ministry of Labor and Social Security and the Ministry of Health required employers not to refuse employment simply because the applicants were found having HBV antigen. ${ }^{28}$ Finally, the highly celebrated Employment Promotion Law, which was promulgated in August 2007, states explicitly that, 'When an employer recruits employees, it shall not refuse to recruit any person under the excuse that he is a carrier of an infectious disease. ${ }^{29}$ A series of laws and subsidiary legislation were subsequently passed to end employment discrimination against HBV carriers.

Riding on the intense media coverage of the two cases and the immense political discussion surrounding Zhou's execution, HBV FORUM promoted a rights discourse by telling discriminatory stories and by naming and shaming government and corporate offenders. But the rights discourse was embedded in the online routine social activities of the HBV FORUM's members, who participated in the online political discussion not merely because of their sense of citizenship or their political motivation. People living with HBV were drawn to HBV FORUM politically because the political participation was embedded in, and incidental to, their social gatherings or information sharing.

Through the informal social gatherings and networking, HBV carriers started their advocacy in a moderate and gradual manner. HBV FORUM, for instance, encouraged its members to write letters to government offices and media outlets to publicize discrimination and express their expectations. ${ }^{30}$ As a result, several HBV carriers were interviewed in China's only national network, the CCTV. Once HBV FORUM organizers and supporters gained some confidence in their ability to mobilize social and government sympathy and support, they saw a future for rights advocacy in China.

An irony confronting HBV FORUM is to promote the rights awareness and encourage HBV carriers to take actions in defending their rights, but at the same time to lower the rhetoric so that the online discussions and dialogues would not invite censorship from the government. That is a difficult balance to strike, given the lack of policy-consistency and predictability in government censorship. Radical and challenging comments do attract official attention, and once that happens, an existential crisis may be triggered. HBV FORUM had its share of government censorship - it was shut down twice in 2007 and 2008 respectively. ${ }^{31}$ In both occasions, HBV FORUM organizers were able to mobilize support in the government and had the HBV FORUM reopened. But because of the potential government censorship, HBV FORUM has started to practice self-censorship to monitor and delete postings that are regarded as offensive and risky on its own initiative. At the same time, it has been calling for calm and rational discussion and the necessity to avoid extreme comments that may bring risk to the HBV FORUM. Lu Jun has been receiving complaints from the members about the forum's self-censorship. Whenever this happened, he would patiently explain that the self-censorship is his strategy for achieving greater good, and also express his determination to delete any postings for this reason. ${ }^{32}$

\section{From Online Mobilization to Offline Activism}


Cyberactivism, however progressive, is limited in effect when it happens only in the virtual world. It is one thing to think critically and to speak out according to one's conscience; it is another thing (and a great leap forward) to act upon one's word in the real world. While online advocacy may have the potential to shape public opinions and influence governmental decision, its impact remains limited if people merely bounce ideas off each other without engaging in challenging activities in the real world. As Internet critics have rightly pointed out, cyberactivism could be irrational, superficial, and of low cost and low impact unless the chaotic forces are organized and channeled to some sharply focused targets and become real world actions. ${ }^{33}$

Online political mobilization may remain important, but it will never replace the conventional offline political action such as street demonstrations. Instead, cyberactivism will mainly play a complementary role to the latter. To cite Wray, 'it is likely that future actions will be neither purely electronic civil disobedience, nor purely physical disobedience. Rather we are likely to see a proliferation of hybridized actions that involve a multiplicity of tactics, combining actions on the street and actions in cyberspace. ${ }^{34}$

The divide between the virtual and real worlds have never been clear. Yang Guobin, for example, has identified three types of online-offline interactions. First, the relative freedom on the Internet allows netizens to generate new ideas, providing a resourceful discursive repertoire for protest in the real world. Sparks on the Internet spill over to the real world. Second, there is the organizational dimension in which citizen activists plan and organize offline activities through information technology including the Internet. Finally, offline activities are fed-back to, and reinforced by, the Internet through instantaneous webcasting and follow-up online reflections and discussion. ${ }^{35}$

By 2005, organizers of HBV FORUM clearly realized the limit of online discussions and spontaneous social gatherings, and a need to organize offline activities through a separate entity. Online mobilization through the HBV FORUM had created a strong antidiscrimination identity in the HBV community and generated a large enough membership in different parts of China who would not hesitate to demonstrate their support to the group. Based on this positive assessment, in December 2006, HBV FORUM spilled over to the real world and a sister, offline, organization called 'Beijing Yirenping Center' was registered as a company to transfer cyberactivism to action in the real world. ${ }^{36}$

As a physical entity, and supported by an influential forum, Yirenping is instrumental in promoting equality rights and organizing and coordinating activities. As a young organization, Yirenping works closely with other NGOs and learns from others' experiences. Upon its establishment, Yirenping was invited to attend a variety of training offered by other NGOs, groups working in the field of AIDS/HIV in particular, such as Aizhixing which has been aggressive and effective in highlighting the sufferings of HIV carriers and AIDS patients and in promoting their rights.

Inspired by the achievement of NGOs in the HIV/AIDS field and realizing the opportunities for social changes through bottom-up citizen activism, Yirenping organized the first national conference in Zhengzhou in 2007. It was a three-day conference with a 
focus on the development of NGOs and equality rights in China. That conference, dubbed the 'Zhengzhou Conference', has been regarded as the landmark in the rights movement in the HBV community, which for the first time, put the diverse and localized HBV groups under a common organizational framework. The one hundred participants of the Zhengzhou Conference formed the core members of the HB rights movement who have since maintained close contact with each other and Yirenping. ${ }^{37}$

Through the online and offline activities over the years, local coordinators have emerged. They are the people who are passionate about the HB cause and available and have the necessary resources and leadership skills in organizing events. In a largely spontaneous way, a tier of leadership, with the coordination of Yirenping, becomes recognizable and is recognized in the HBV community. They serve as the bridge between Yirenping and the masses in the HBV community in different parts of China. The Zhengzhou Conference confirmed their leadership role and provided a platform for horizontal coordination among community organizers in different parts of the country.

Local working groups perform three principal functions: First, they organize welfareoriented activities to serve the local HBV community, including the traditional social gatherings and public lectures on medical intervention or other health-related subjects. That is in response to an immediate need in the society, and also to reduce the political sensitivity associated with social mobilization. Organizers reiterate the importance of welfare-oriented activities and embed the rights-oriented activities in the welfare-oriented activities. HBV FORUM online and Yirenping offline have become a magnet, drawing the community of people living with HBV together to work towards a common cause. ${ }^{38}$

The second function of the local working groups is to provide a variety of general and targeted education and targeted protest, including 'behavioral arts' in public places; training of student volunteers; and providing anti-discrimination training for fresh university graduates during hiring seasons. Yirenping allocates a large proportion of its resources to providing services to young university graduates who are easy targets of discriminatory practices. For example, Yirenping published a handbook, with a step-bystep guide, to help victims of HB-discrimination. ${ }^{39}$

The third function of the local groups is to organize anti-discrimination litigation. For Lu Jun, online discussion on those cases served an educational process that raised the awareness of HBV carriers. Through participating in discussion with their peers, people living with HBV became less fearful in reporting discrimination as they had experienced it, and became more vigilant in reporting when these cases were observed. Gradually, they become more aggressive and organized in their online campaigns and offline activism. In 2005, for example, when a case was brought against the State Tax Administration in Hunan for its discriminatory recruitment policy, many HBV comrades traveled to Changsha to attend the trial and also organized a small rally in front of the court with a banner. ${ }^{40}$

No resistance is possible without online mobilization. The Internet has proved a necessary, cost-effective instrument for organizing social movements in China. In promoting and 
protecting the rights of people living with HBV, movement organizers use HBV FORUM to create a collective identity, sustain a virtual community, and generate solidarity among its members. HBV FORUM also allows the organizers to develop a better understanding of the daily struggle against discrimination and the difficulties encountered by people living with HBV. It is strong in facilitating horizontal communication and coordination within the HBV community in different parts of China, although it has been weak in facilitating any dialogue with government authorities. ${ }^{41}$

Cyberactivism also lays a solid cultural and psychological foundation for future action. Through the repeated online discussion on HBV-related medical, social, legal and political issues, netizens in the HBV FORUM are not only able to sustain a sharply focused interest, but also become more confident and fearless, and are ready to speak in one strong voice with consistency and tenacity.

But the HBV FORUM alone is not sufficient to create and sustain a rights movement. The success of the HBV FORUM also highlights the weakness of cyberactivism and necessitates the creation of Yirenping as a physical entity in the real world to confront real world problems. The cyber world is filled with passion and rhetoric but is short of concrete actions to confront individual perpetrators in a meaningful way. Without any real world action, cyberactivism is likely to produce a false sense of empowerment for the HBV community. The online mobilization and offline action have to supplement each other and become mutually reinforcing to promote and sustain equality rights. In the HBV cases, HBV FORUM does all it can to promote news, create sensation, attract attention, and mobilize support, but it is Yirenping that brings ideas into practice by coordinating street actions, organizing training and bringing cases to courts. In other words, the HBV FORUM provides a 'home' and a safe harbor for people living with HBV while Yirenping mainly serves as a sword to launch attacks on discrimination. Through this intensive online-offline interaction, with public interest litigation at the core, activists contribute to legal, policy and cultural changes.

\section{Participation through Litigation}

HBV FORUM as a virtual entity has limited capacity in organizing legal action in the real world. It was therefore only after the establishment of the Yirenping Centre that anti-HB discrimination litigation becomes more organized and effective. In 2003, when organizers of HBV FORUM started to search actively for suitable cases for litigation, the task was difficult because much of the discriminatory practice were simply taken for granted. Also, there was little publicity when discrimination took place. The cases of Zhou Yichao and Zhang Xianzhu were a wake-up call for the HBV community and the society at large.

Litigation against HBV-discrimination was rare in the subsequent three to four years after 2003. To spot new cases, Lu Jun, for example, would spend a few hours every morning going through the postings in HBV FORUM. There were less than 20 cases between 2003 and 2006. Cases started to pick up after 2006. In 2007, 13 cases were brought to the courts. ${ }^{42}$ From 2008 onwards, approximately 70 to 80 anti-discrimination cases were brought to courts each year, including about 50 cases related to HB-discrimination. By 
now, litigation and activities surrounding litigation have formed the core activities of Yirenping. $^{43}$

There are two types of HBV-related discrimination. The first type relates to preemployment medical check-ups and discriminatory employment policies based on the result, i.e. pre-employment discrimination. The second type relates to discriminatory policies toward existing employees who were tested HBV-positive during the course of employment, i.e. in-employment discrimination. Different types of cases are of different natures in terms of their legal procedures and remedies. The defendants may differ, too.

In-employment discrimination takes place after the formation of a labor relation. It is regarded as a labor dispute and, in Chinese law, is subject to the special regime of labor law. As required by the relevant legislation, the plaintiff needs to apply for labor arbitration to a local labor arbitration committee and then sue the defendant in court if dissatisfied with the arbitral award. The pre-employment discrimination, on the other hand, is an ordinary civil matter, and the plaintiff is allowed to bring the case directly to court for remedy. But a court may conflate the two types of cases and demand labor arbitration as a pre-requisite to litigation in both discrimination cases.

Depending on the route that one is to take in a legal action, a person alleging discrimination may sue the employer and the hospital which performed the medical check-up in a civil action and a government department with supervisory responsibility in an administrative action. In suing an employer, however, the strong advice of Yirenping is to join government departments as defendants in the lawsuit so as to generate political pressure on the employer. ${ }^{44}$

Cause of action in civil anti-discrimination lawsuit has been a contentious issue and a case can be easily thrown out by judges for lacking an explicit cause of action in Chinese law. The cause of action is invariably the infringement on the right to equality. Equality right is protected by the Chinese Constitution, ${ }^{45}$ and during the life time of the Supreme People's Court (SPC) interpretation on the Qi Yuling (齐玉苓) case, lawyers referred to the equality clause in their submission. After the abolition of the Qi Yuling Interpretation, although lawyers are refrained from referring to the Constitution directly, they continue to refer to equality rights by citing the Party's documents and speeches of political leaders. ${ }^{46}$

For judges to accept a case, there must be a specific cause of action as provided in the List of Causes of Action in Civil Proceeding as provided by the SPC (Cause of Action List). Discrimination infringing on equality right is not a prescribed cause of action and thus not actionable. When a HBV case is acceptable by a court, the cause of action is always 'a general personality right', which, as argued by Yirenping lawyers and accepted by judges, would include 'equality right'.

Yirenping's litigation strategies have also evolved over the year in responding to legal and policy changes and the corresponding opportunities. Before the State Council's reversal of its discriminatory policy on civil service recruitment, Yirenping-generated litigation targeted government departments, challenging the legality of the discriminatory 
policies on the ground of constitutional and legal right to equality. Given the official discrimination, Yirenping rarely won a case. After the State Council's reversal of policy, the focus of litigation shifted to the implementation of existing rights the private sector. With clear legal rights on the book, judges become more supportive and Yirenping started to win cases. Over the years, Yirenping has become a repeat player, in Galanter's terms, ${ }^{47}$ in anti-discrimination cases and developed a well-honed modus operandi in handling the plaintiffs, defendants, courts and media.

\section{Handling Clients}

The years subsequent to the establishment of Yirenping witnessed a dynamic relationship between online mobilization and offline action at its best in China, which showcased the potential of civil society-led reform and the optimum level of achievement.

Yirenping has developed a better structure since its establishment to receive complaints of discrimination. Members in HBV FORUM, now estimated at 400,000 and continuing to grow, are able to feed in a relatively large amount of information, including many potential cases, to Yirenping for action. Serving as a national centre, Yirenping has developed stronger capacity to process information and assess the merits of potential cases. For example, it maintains regular contact with informants or potential plaintiffs to develop cases through email and other information technology, and relies on a team of dedicated public interest lawyers to provide an initial assessment of those potential cases. $^{48}$

After having found the potential cases, there is an intense communication and consultation among Yirenping lawyers, local coordinators and the victims. While there are many legal and non-legal hurdles, no different from other public interest NGOs, one typical difficulty facing Yirenping is to locate a proper plaintiff who is willing to sue. It has been a common problem that victims of discrimination and other abuses, their family members in particular, are reluctant to publicize the suffering and bring the case to the court. To overcome this difficulty, Yirenping decided to focus on fresh university graduates who are in a process of job searching. These young people are often in cities and away from their families, and therefore more dependent on the assistance offered by NGOs and with less interference from family members. ${ }^{49}$

To provide protection and incentives for litigation, Yirenping has also taken three steps to ease the concerns of potential plaintiffs. The first step is to make litigation financially attractive. ${ }^{50}$ This has been a controversial issue in the community of public interest lawyers. Many strongly believe that public interest litigation should be for non-profit purposes and a fight on purely moral ground, hence the popularity of one dollar lawsuit in which a plaintiff demanded an apology plus one Chinese dollar as compensation. ${ }^{51}$

But Yirenping takes a different view, and the prevailing practice of Yirenping is to demand as much monetary payment as possible. Of course, any compensation awarded by the courts or through settlement will go to the plaintiffs, thus serving a strong incentive for victims to come forward. Indeed, it is also the policy of Yirenping to request 
its lawyers to demand a figure as compensation higher than the law permits on the ground that the courts may go, and have gone in some cases, beyond the legal limit. This, plus media promotion, will send a stronger message to the defendants and strengthen the bargaining power of the plaintiffs in settlement. ${ }^{52}$ To do this, Yirenping has to carry out intense negotiation with its lawyers on the exact figures to be demanded. Professional lawyers, as dedicated as they are to the HBV community, are reluctant to ignore legal restrictions and they would try to avoid any embarrassment in front of their peers and judges. The more professional the lawyers are, the more deferent they are toward law and judges, and the less aggressive they become.

Professional lawyers may be too conservative for Yirenping in their deference to legal rules, and Yirenping prefers counsels who are willing and able to challenge legal restrictions such as fee caps in awarding compensation and damages. In any event, antidiscrimination lawsuits, especially in the specific context of HBV-discrimination, are alien to most lawyers including those who are willing to assist in these cases. Due to these concerns, the second step that Yirenping has taken is to train its own in-house barefoot lawyers from active members in the HBV community to provide pro bono legal services. ${ }^{53}$ As mentioned earlier, a generation of netizen activists from the HBV community has emerged through cyberactivism associated with HBV FORUM. Very often, because of their personal experience, HBV netizen activists passionately participate in the online discussion and dialogue, and some of them become the core members in their own local HBV community. It is in the process of engaging in online and offline activism that some participants make the transition from a passive observer to a netizen activist, and from an occasional advocate to a professional working on a full-time basis. In that process, they take a strong identity as rights defenders and spokespersons of the HBV community. With their passion and dedication to the cause, the HBV netizen activists become the barefoot lawyers who specialize in HBV-discrimination cases after attending training organized by Yirenping. Living with HBV themselves, these HBV netizen activists have the medical expertise and technical knowledge regarding testing and medical evidence; as repeat players, they become experienced in dealing with the courts and in handling evidence; and as local coordinators of the HBV community, they have the necessary personal and leadership skills to mobilize local resources to promote their cause.

While the socio-legal activists actively pursue and aggressively litigate cases in courts, they identify themselves more as mobilization leaders than litigation lawyers. Compared with professional lawyers, mobilization leaders feel less constrained by legal rules and professional conduct expected of lawyers. These netizen activists are more partisan and have developed a sharp sense of interest for, and an identity with, their own constituency. Yirenping is satisfied with this new arrangement - potentially of low cost-high impact and with more direct control from Yirenping. There has been a clear shift in some of the provinces, Guangdong in particular, from relying on outside lawyers to developing their own in-house barefoot counsels. Most of the cases handled by these in-house counsels settled to the satisfaction of the plaintiffs. ${ }^{54}$

The third step taken by Yirenping is to protect the privacy of the plaintiffs. A principal 
concern of the plaintiffs is publicity of their identity and the potential adverse effect publicity may bring about. Recognizing this legitimate concern, Yirenping has developed a detailed protocol to conceal the identity of plaintiffs, and it has been professional and effective in implementing the protocol. For example, it is proactive in briefing media of any new case that it sponsors, but as a condition of media coverage, Yirenping insists on the use of pseudonym for its plaintiffs. Photo taking is also carefully arranged so that the face of plaintiffs would not be recognizable. Yirenping has also been successful in obtaining cooperation from the courts in protecting the plaintiffs' identity. ${ }^{55}$

\section{Handling the Courts}

Once a plaintiff is identified, the next procedural hurdle in anti-HB discrimination is to convince a court to accept the case. Acceptance has become a common difficulty in the so-called 'sensitive cases' or 'cases without interest for the court to extract'. Yirenping's strategy, which has proved to be effective, is to let the judge know that the plaintiff is looking for a quick settlement and the settlement, according to Yirenping's record, is feasible. According to Yirenping, a demonstration of the will to settle through mediation creates an incentive for the court to accept a case which it may be otherwise reluctant to accept. It is because, settlement through mediation has become a preferred method of dispute resolution in Chinese courts, and judges receive merit bonus for cases that are resolved through mediation.

An added incentive for Yirenping to settle is the fact that settlement yields better outcome for the plaintiffs. Chinese law allows no punitive damages and the quantity of damages is often small for discrimination cases. Defendant enterprises, facing adverse publicity and public pressure online and offline, as will be described below, are willing to settle. Most of the cases that Yirenping sponsored were solved through settlement. The amount of the settlement fees varied. For pre-employment discrimination cases, it varied between 30,000 and 50,000 RMB, a significant figure for fresh university graduates who constitute the main body of plaintiffs among Yirenping-sponsored lawsuits. ${ }^{56}$ The highest damages awarded by a judgment after trial was only 19,000 RMB. For in-employment discrimination cases, the highest settlement was 250,000 RMB for three employees while the highest damages awarded after trial was $40,000 \mathrm{RMB}^{57}$

In convincing the courts to accept a case and to revolve the case in a way that Yirenping prefers, Yirenping lawyers offer help to judges in charge of their cases. HBV-related litigation is rare and judges seldom encounter legal issues of that particularly kind. To familiarize judges with the issues, Yirenping lawyers actively approach judges and pass on decisions that have been made by other courts, previous settlement agreements and related news reports. With the precedents in hands, judges have reference points in mind and are likely to make similar decisions.

Facing uncooperative and obstructive judges, Yirenping has designed its own tactics: making complaints against individual judges to judicial supervisory departments. Yirenping, through its clients, has launched a series of complaints against judges who either refused to accept a complaint or gave an adverse judgment. For example, after 
losing a case against a manufacturing factory in Shenzhen, the plaintiff wrote a stronglyworded letter to the trial court and the superior court. In addition to accusing the trial judge of a 'very low level of expertise' which led to 'a judgment with many common sense and legal errors', the plaintiff stated:

In the larger environment today when the political-legal system stresses the superiority of people's interest, the trial judge in this case totally ignored my lawful request and showed no care to serious pains that I suffered physically and mentally. [The judge] put aside the legal requirement and refused to accept my case that he should have accepted according to legal provisions. In doing so, the judge violated the requirement of our Party that courts should be 'the courts that the people are satisfied with.

In the circumstances where the Party and the state have paid special attention to the problem of employment discrimination against HBV carriers and protective legal provisions have continuously been promulgated, the trial judge in this case treated the legal provisions as window dressing. He also sabotaged the policies and spirits through which the Party and the state give cares to HBV carriers. ${ }^{58}$

Yirenping's ultimate weapon is an open letter to denounce the court on the Internet and in the court of public opinion. While the complaint against a judge is made by the plaintiff, the open letter is signed and released by Yirenping. In an open letter against the same district court in Shenzhen, for example, Yirenping made a number of serious accusations on both procedural and substantive issues: Procedurally, Yirenping accused the court of unlawfully creating legal barriers to prevent the plaintiff's case from entering the judicial process, and in doing so 'made a mockery of law'; substantively, Yirenping accused the court of lacking elementary medical knowledge about HBV and basic competence in handing the case. In Yirenping's view, in rendering the decision as it did, the court distorted the facts and violated law. In the open letter, Yirenping also seized the opportunity to air its wrath over the discriminatory laws and practices and the aspirations of 'near 100 million HBV carriers'. 59

The open letter was not merely an open demonstration of shock and anger. It also served as a reminder to the appellate court of the errors that the lower court made. The open letter stated toward the end: 'The plaintiff in the case has brought an appeal, but can the appellate court try the case fairly according to law and correct the unlawful judgment given by the (district) court? We wait with great vigilance! ${ }^{60}$

\section{Managing the Media}

At every stage in the case development, Yirenping projects a positive image about the case and its effort to the traditional and electronic media. ${ }^{61}$ When a discrimination case is identified, Yirenping would provide the media with the details of the case and the identity of the defendant(s). Meanwhile, the HBV community would be mobilized to publish commentaries on HBV FORUM to show their support to the plaintiff(s) and to attack the defendant(s) and the discriminatory practice(s). The online and offline naming and 
shaming are meant to bring pressure to government authorities to intervene and to the defendant(s) to settle.

When a case is filed with the court, Yirenping again sends out celebratory messages, claiming that the court and the legal system are on its side in defending the rights of the victims. When the date of hearing is fixed, Yirenping invites the media to attend the trial and to cover the court proceeding, and also requests the respective local HBV community to show support. Finally, when a decision is rendered, Yirenping also claims victory through media. ${ }^{62}$

Yirenping has tried to make the work of reporters easier by preparing detailed, welldrafted press releases so that reporters could write their own pieces with little effort. Some reporters picked up the press releases from Yirenping and convert them into an article while some lawyers and reporters also wrote a piece on their blogs. The press releases are so professional that in several occasions they were simply adopted and reproduced by newspapers.

Anti-discriminatory litigation is politically safe because they touch upon an ordinary right of ordinary and isolated individuals. The plaintiffs are simply claiming a legal right that is being promoted by the government. For reporters in particular, Yirenping is a moderate organization and has been covered and promoted by the top official media. Yirenping itself has made extraordinary efforts in maintaining a positive image for itself in the media so that the organization would appear legitimate for reporters and the society at large. Anti-discrimination lawsuits are also exciting and attract readership. There is a strong incentive for the media to cover that sort of news to improve their circulation and to attract readership. Other efforts Yirenping made to improve its relations with the press include the offering of free training courses for reporters on the coverage of legal news. ${ }^{63}$

Once a Yirenping event appears in the press or a blog, it becomes another news item for the HBV community. The news would be reported back to HBV FORUM with amplification. Any official coverage of HB-related events, however marginal it is, would be treated as a great victory by the HBV community, highlighted and amplified in HBV FORUM. To the HBV community, an Internet report on a discrimination case would be interpreted as public outrage against the discriminatory practice, and the coverage of a case in the official media would be treated as a serious government attention to, and support of, the rights of HBV carriers. The key strategy of Yirenping's media campaign is selective use of media reports and a positive 'spin' of the public information to fit the purpose of the HBV community. ${ }^{64}$

Following a round of positive reporting, there are also well-coordinated responses from the HBV community to the amplified re-publication of the news. Depending on the nature of the reported news, the audiences either cheers and celebrates the victories or expresses their anger and condemnations. Through this almost ritualistic cycle of news management, Yirenping keeps anti-HB discrimination a live issue in the public sphere and at the same time motivates and urges its members to carry on the advocacy. News management also has a practical use. Once a round of media campaign is completed, 
Yirenping lawyers would gather the reports, especially those from the official media, and send them to the management in the defendant companies. After public opinions are effectively channeled to the management level, it is expected that defendant companies would be more willing to re-consider their position and agree to settle the case.

\section{Socially Embedded Socio-Legal Activism}

What makes Yirenping special? Yirenping's active use of law is different from both the litigation-centric approach of passive reliance on law and the street-oriented approach of radical challenge of law.

At one end of the spectrum of socio-legal activism is a moderate approach in which some groups focus on the litigation of individual cases to bring legal pressure to bear on their adversaries. Vulnerable groups with little social capital and political resources, such as migrant workers and victims of environmental pollutions, tend to depend on law by bringing real or perceived injustice to the attention of legal institutions. They bring their individual legal cases, one by one, to court to assert their legal rights and demand monetary compensation. Within this conceptual framework, litigants go to court with the understanding that each dispute is provided with a corresponding legal remedy and access to court is treated as the equivalent to access to justice. The government prefers the litigation-based activism because individualized legal action deflects political contention and helps to legitimize and stabilize the existing political order. By focusing on legal rights of individual litigants and the immediate legal remedies, the legal process isolates what could otherwise be explosive social and economic contention.

At the opposite end of the spectrum is the more aggressive advocacy of rights with the use of more radical approaches (in the Chinese context) where activists move beyond the legal arena, for the law offers only empty promises. In the example of environmental litigation, the difficulties that litigants face in environmental cases are well documented. For environmental lawyer Wang Canfa (王灿发), hardship accompanies every step of the litigation, from gathering evidence to court acceptance of the case; and from judicial decision-making to enforcement of judgment. ${ }^{65}$ According to Alex Wang, another authority on Chinese environmental law, plaintiffs in environment cases have little hope of winning and little confidence in court in delivering justice. ${ }^{66}$ The demise of litigation in environmental cases applies equally in labor disputes, where the institutional design is largely seen as a legal trap which sucks workers into a dark tunnel and once in it, few can see light at the other end.

The institutional failure of litigation provides fertile grounds for extreme measures and radical activism. Two types of radicalism have emerged. One type of radicalism relates to the extreme measures that are taken in defending rights. In environmental cases, for example, self-help by the victims has taken the form of destruction of property belonging to polluting factories or obstructing their operation, such as cutting off power or damaging equipment; blocking entrance and chasing away employees, etc. Those drastic actions often end up with direct confrontations between protesters and the police and 
invite state repression. In labor disputes, extreme measures include self-maiming, suicide and various forms of blockages.

The other type of radicalism is political advocacy where politically-motivated activists are determined to test and push the political boundaries. The activists touch on issues that are declared as politically sensitive and off-limit; they organize and mobilize social groups to join force in claiming their collective rights, with lawyers playing certain leadership role in an emerging civil resistance; and the activists work with, and receive support from international NGOs, foreign media, and foreign governments, including the hostile ones. In the process, the activists challenge law, in both the court of law and the court of public opinion, by pointing out the law's failure to hold the Party accountable. These forms of resistance represent an emerging civil disobedience.

The Party makes drastically different responses to different types of rights lawyers. For example, the Bureau of Justice (BoJ) of Beijing disbarred Tang Jitian (唐吉田) and Liu Wei (刘巍) because of their aggressive defence of their Falun Gong clients in court. ${ }^{67}$ At the same time, it lauded Tong Lihua (佟丽华), a moderate lawyer, as an exemplary lawyer for his provision of legal aid to migrant workers. ${ }^{68}$ The government suppresses the radical socio-legal activism that may be drawing the otherwise isolated social forces together and channeling them to confront the Party. This potential to organize and mobilize the masses has caused the government to become more hostile and repressive, seeing lawyers as organizers of an emerging social force for transformative politics, who, backed by hostile international forces, may develop the potential to create formidable political dissent.

Yirenping activists make active use of law and tread in the place in between passive reliance and radical challenge. The success of Yirenping depends on the quality of the community it represents, the unique position of HBV carriers in China's regulatory space, and the organizational capacity of Yirenping itself.

First of all, the quality of the HBV community matters. Yirenping works with HBV carriers who are a unique group of people in the society. The HBV community is big in size, and according to civil resistance literature, size matters. With a constituency of over 100 million people, and more than half million of them registered on Yirenping's website, the HBV community is a very vocal and resourceful group. Other groups, such as those who support sex workers, HIV/AIDS or pneumoconiosis patients, and even environmental groups, pale in comparison.

The HBV community is also a stable community in membership and captive audience. Given the nature of the disease, HBV carriers exchange information on medical issues and other social concerns that are unique to that particular group. Similar to disability, $\mathrm{HBV}$ is a permanent feature to its carriers and is a life time concern involving both multiple medical and social issues. But different from disability, members in the HBV community otherwise engage normal life in society and are attached to their respective families and communities. HBV is not fatal. The fact that it is not fatal makes it very different from HIV/AIDS and pneumoconiosis (as the case is in China). Facing no 
immediate deterioration in health, members in the group are willing to gather together to converse on treatment or job prospect, or simply to socialize or complain. Because of the stickiness of the issue and the stability of the HBV community, it is easier for members to be organized, maintain in touch and develop a coherent voice of their own.

But the HBV group does not manifest any extremist potential partly because the level of its organization also militates against any radical collective action. Different from factory workers who are better organized and disciplined because of the industrial setting, HBV community is stable but loosely organized. While an emerging organized labor movement, frustrated with the lack of progress that litigation may bring, is willing and able to take certain political action by organizing themselves, and taking industrial actions and bypassing the official unions to directly bargaining with the management, the HBV community would gain more through their litigation-based legal activism. This is a group at some moderate risk who make some moderate claims at policy changes. Indeed, the HBV community's demand largely relates to the enforcement of existing legal rights relying on existing law. Yirenping leaders are eager to project a positive image of HBV members as neither fatalistic who have given up on trying nor radicals who are desperate enough to take extreme actions. After all, HBV does not carry a moral stigma and attract a moral condemnation that other groups, such as sex workers, HIV/AIDS patients, people with different sex orientations or drug addicts, would do. ${ }^{69}$

In developing the capacity among its members, Yirenping strengthens itself in the process. It is an organization that is built from within out and from bottom up. Many Yirenping staff members and other activists are themselves HBV carriers, who come from the community which they represent. They have common concerns and common interests. They can speak in the same voice. In that sense, Yirenping is compatible to a faith-based organization, such as the Christian house churches, in which shared status, experience and aspiration tie the members together. There is a common identity to cultivate and a common interest to fight for, all making the struggle resilient.

In addition to size and stability, a more crucial quality the HBV group possesses is the fact that it is widely represented in the population in terms of gender, age and residence. HBV carriers do not draw from a particular group of the society and, while some of them are poor, a significant proportion of people in the group are well-resourced. As mentioned earlier, China only started rigorous pre-employment medical check-up to screen out HBV carriers in the late 1980s. Many HBV carriers are now in the government, with some occupying senior positions in different departments including the police. ${ }^{70}$ Yirenping, in advocating rights for HBV carriers, draws resources and support directly or directly from government officials who identify with, or at least sympathetic to, the campaign. On the platform provided by Yirenping, HBV carriers within the government work, side by side, with actors outside the government.

Second, the position of the HBV group in China's regulatory space matters. The HBV group occupies a special place in the governance structure and presents a gap in the Party's otherwise comprehensive network of control. Thus, labor rights are the monopoly of the official labor union; gender issue falls within the exclusive jurisdiction of women's 
confederation; and a confederation of disabled persons exists to manage affairs of the physically challenged. Those official mass organizations, as they are officially referred to, are extensions of the Party/state which serve the first port of call for the respective constituents. They provide services to the respective groups and, in the process, capture the issues at the exclusion of other groups outside the system. Gender issue is thus the prerogative of the women's confederation and the official labor union owns labor issues. These organizations control their constituents while serving them.

The official organizations occupy their respective fields and develop a monopoly. Politically and legally, they exclude any effective, independent participation of others, reducing them to the role of a supplementary outsider. As institutional actors, they are hostile to possible intervention from external sources and have little incentives to work with outsiders. For example, the official labor union is instrumental in suppressing grassroots labor organizations; women's confederation curbs the growth of women's NGOs; and confederation of disabled persons is effective in creating and reinforcing dependence and loyalty of its constituents.

Without any corresponding official organization in the same field, Yirenping exists, and at the same time, also fills an organizational vacuum. In representing its constituents, Yirenping has met no serious competition and received little resistance from official organizations. It simply covers a field with issues that the official organizations only have marginal interest, or they are actually happy to push away. The official labor unions break strikes and suppress the spontaneous labor organizations in factories; and the disabled persons' confederation decides the rights a disabled person may claim and the channel and manner to make a claim. Had the government developed an anti-HB discrimination body in the same way it establishes the official labor union, the HBV issue would have been hijacked and distorted.

Finally, and, for Yirenping, most importantly, organizational skill matters. With the resources that Yirenping has, it organizes its campaigns effectively. Yirenping could actively use law as a stepping-stone to launch a larger social campaign. Litigation is not the end of the campaign but only the beginning. Indeed, resources and energy are mostly spent not on court action but on activism outside the court room to magnify the issue, enhance awareness of the general public and nudge the system forward on equal treatment and non-discrimination. Thus, judges are only the first person that Yirenping want to speak to, and court room serves mainly as a stepping stone to engage in broader media mobilization, social mobilization and political mobilization. Admittedly, this strategy is commonly used among public interest groups, and indeed a standard one which can be replicated in dealing with any issues. But Yirenping, with excellent organization and management skills, has consistently applied the strategy with success.

The partial success of the litigation-centric strategy, with the support of the victims and the tolerance of the government, is attractive to Yirenping and other leaders. Experiences accumulated in the past decade allows Yirenping to develop a unique modus operandi, a team of professionals well-trained in the art of legal activism, and a particular way of thinking about rights advocacy in China. This does not mean that Yirenping does not face 
challenges or it does not challenge the system in its policy advocacy. Instead, this means it generates its own path-dependence and tends to solve the problems with institutional means. Therefore, it fought courageously against censorship and twice forced the regulators to reopen its website, but at the same time it censors its own members and deleted controversial and offensive speeches; it organizes behavioral arts on streets to promote their cause, but never allows it to grow into a public demonstration - typically, Yirenping members perform, take photos and circulate pamphlets in a fast pace and manage to disappear before the police arrive; and it commemorates Zhou Yichao and has built a virtual shrine in the HBV FORUM, but cautions its members to limit to institutional measures in taking action. The nature of the campaigns and the status of the membership have precluded any radical action from Yirenping as an organization.

\section{Conclusion}

Facing a limited political opening in the state and a cognitive liberation among citizens, different social groups repositioned themselves and, through socio-legal activism, asserted their rights and interests. There are divisive political stances among different groups which adopt different methodologies in advocating rights for their respective groups. They relate differently to law and engage the state through different pressure points. Some depend on the law, others challenge the law, and the more successful ones actively explore the law's potential in engendering a rights movement.

Litigation-centric legal dependence generates only limited return in China's political and social circumstances. More radical advocacy that challenges the state receives hostile pushback. Both approaches have limited space in China. A middle way approach proves to be more effective, and Yirenping has been exemplary in offering a middle, ameliorative model of rights movement. Embedded in the HBV community, Yirenping uses litigation as a catalyst for broader public participation in decision-making. One of the key functions that Yirenping plays is to sustain a high level of public attention to HBbased discrimination and it does so through media promotion of its causes, Internet mobilization of its members, and moderate but creative demonstration of social forces. Through a chain of mobilization among its members, in the larger society and within the political system, it makes sure that the decision-maker, either a corporate body or a government department, meets a strong direct pressure which forces them to make a response.

Yirenping, through its litigation-based approach and the mobilization of the community in which it is deeply embedded, becomes a stabilizing force in society. It reduces radicalism and the risk of extreme measures in the HBV community. In that sense, the anti-discrimination socio-legal activism

may prove more system-supportive than system-subversive. In an authoritarian polity, where elections do not provide an effective check on the misbehaviors of the state authorities, protests can help to serve the function - thereby undergirding rather than undermining the political system. ${ }^{71}$ 
At the same time, the socio-legal activism also creates some legal and institutional constrains on state power and brings official behaviors onto a legal framework.

As an advocacy NGO, Yirenping's political stance and the methodology depend on the motivation and capacity of its leaders and lawyers who, in turn, also depend on the political will and capacity of the community that the organization seeks to represent. The moderate nature of the HBV community creates political constraints on their representatives, ensuring that Yirenping cannot run too fast, leaving the community it seeks to represent too far behind. Organizational skills and political will of leaders matter, but the quality of the constituent community and the context in which the community exists matter more. As such, Yirenping, embedded in the HVB community, has adapted a strategy - a moderate one based on legality and the rule of law, that can best serve the collective interest of that community.

${ }^{*}$ Faculty of Law, the University of Hong Kong. The author would like to thank Lu Jun, Huang Yizhi, Zhang Lingji and other staff members of Yirenping for your continuous support and thank Anne Cheung, D W Choy and Mike Dowdle for their comments on an earlier version of the paper.

${ }^{1}$ The official website of Yirenping is available at: www.yirenping.org/ (accessed 10 October 2010).

${ }^{2}$ The URL of HBV FORUM is available at: www.hbvhbv.com/forum/ (accessed 10 October 2010).

${ }^{3}$ The predecessor of HBV FORUM was an Internet forum attached to the website of HBV Carriers' Association. It was only re-named as 'Gandan Xiangzhao' on 30 September 2001 after it registered the domain name as 'hbvhbv.com'.

${ }^{4}$ Gongmeng, also known as 'Open Constitution Initiative', was a mainland NGO providing legal assistance to the public and promoting transparency of government. Well-known cases that Gongmeng had involved include the Sanlu tainted milk incident, and the investigation into the Tibet Riot in 2008. Gongmeng was shut down by the Chinese government in July 2009 on the ground that 'it carried out its activities in the name of a private non-enterprise unit without registration and authorization' in violation of the Provisional Regulation of Registration and Management on Private Non-Enterprise Units. 'Law Research Center Is Shut Down as Authorities Tighten Control on Civil Society Groups', Human Rights in China, 17 July 2009. Available at: $w$ ww hrichina org/content/320 (accessed 18 November 2011).

${ }^{5}$ The Center for Women's Law Studies \& Legal Services was a research institute of Peking University. But it was shut down by the Peking University in March 2010. The Center for Women's Law Studies \& Legal Services was subsequently renamed as the Beijing Zhongze Women's Legal Counseling and Service Center (北京众泽妇女法律咨询服务中心) and affiliated with the Beijing Qianqian Law Firm - a public interest law firm established by Guo Jianmei in 2009.

${ }^{6}$ This paper relies on extensive interviews with staff members of HBV FORUM/Yirenping between 2008 and 2010 in Hong Kong, and survey of documentation that are either available on HBV FORUM or unpublished papers provided by Yirenping.

${ }^{7} \mathrm{Fu}$ Hualing and Richard Cullen, 'The Development of Public Interest Litigation in China', in Po Jen Yap and Holning Lau (eds), Public Interest Litigation in Asia, London: Routledge, 2011: Chapter 2.

8 Ethan Michelson,"Lawyers, Political Embeddedness, and Institutional Continuity in China's Transition

from Socialism." American Journal of Sociology (2007) 113, 352-414.

${ }^{9}$ Gang Lu, '485 millions Internet users and 195 millions microblog users', TechNode, 20 July 2011. Available at: http://technode.com/2011/07/20/china-485-millions-internet-users-and-195-millionsmicroblog-users/ (accessed 18 November 2011).

${ }^{10}$ Guobin Yang, 'How do Chinese civic associations respond to the Internet? Findings from a survey', The China Quarterly 189, March 2007: 132.

${ }^{11}$ The first set of discrimination law against HBV carriers was the Rules of the State Labor Bureau and the Ministry of Health which banned the enrollment of anyone with chronic hepatitis into technical training institutions. State Labor Bureau and Ministry of Health, Detailed Rules on the Standard and Implementation of Health Check in Student Enrollment for Technical Training Institutions (Trial Implementation) (12 April 1980).

${ }^{12}$ Ministry of Personnel, Interim Provisions on the Recruitment of Civil Servants (7 June 1994). 
${ }^{13}$ Regulation on the Management of Hygiene in Public Places (1 April 1987).

${ }^{14}$ Article 26 of the Food Hygiene Law provided that, 'no one suffering from ... viral hepatitis transmitted through the digestive tract ... may engage in work with ready-to-eat food.'

${ }^{15}$ Supr, note 12

${ }^{16}$ Beijing Yirenping Centre, 'Understanding and challenging employment discrimination against people living with HBV in China (January 2010)' (On file with the author).

${ }^{17}$ In 2005, HBV FORUM published a book which contains a lot of useful medical information relating to HB provided by medical practitioners and experienced HBV carriers. Gandan Xiangzhao, Zhansheng Yigan [Winning in the Battle with Hepatitis B] (Oriental Press, 2005).

${ }^{18}$ Interview with one staff member of Yirenping, January 2010.

${ }^{19}$ For the details of this case, see for example, 'The case of stabbing a civil servant to death by a student of Zhejiang University: Zhou Yichao was executed by lethal injection', Xinhuanet, 3 March 2004. Available at: http://news.xinhuanet.com/legal/2004-03/03/content_1343729.htm (accessed 20 September 2010).

20 'The first Hepatitis B case in our country: It is a "collective action"', Xinjing Bao [bjnews.com.cn], 26 November 2003. Available at: Nanfang Wang [southen.com], $<$ http://www.southcn.com/news/community/shzt/yg/ygtop/200312180002.htm > (accessed on 5 October 2010).

${ }^{21}$ 'All the media in the country focus on "Hepatitis B discrimination"', Sichuan Xinwen Wang - Chengdu Wanbao [newssc.org], 15 November 2003. Available at: Xinhuanet, $<$ http://big5.xinhuanet.com/gate/big5/news.xinhuanet.com/newscenter/200311/15/content_1179802.htm $>$ (accessed 5 October 2010).

${ }^{22} \mathrm{Ibid}$.

${ }^{23}$ 'The court debate of the first case of Hepatitis B discrimination lasted for four hours: The court will deliver the judgment another day', Zhongan Wang [anhuinews.com], 22 December 2003. Available at: Zhongan Jiankang

[health.anhuinews.com], $<$ http://health.big5.anhuinews.com/system/2003/12/22/001202262.shtml > (accessed 5 October 2010).

${ }^{24}$ The medical report failed to prove that the plaintiff was a HBV carrier. 'Administrative Decisions of Xingwu District People's Court (Zhang Xianzhu v. Wuhu Human Resources Bureau)', in Zhou Wei, Fan Qishi Fa Yanjiu: Lifa, Lilun yu Anli [Studies on Anti-Discriminatory Law: Legislation, Theories and Cases], Beijing: Law Press, 2008.

${ }^{25}$ '1611 citizens initiate a litigation in the name of 120 million Hepatitis B virus carriers', Zhongan Wang [anhuinews.com]. Available at: Zhongan Jiankang [health.anhuinews.com], $<$ http://health.big5.anhuinews.com/system/2003/11/26/001198852.shtml> (accessed 5 October 2010).

26 'Follow-up on the "First Hepatitis B Discrimination Case": The relevant authorities have already amended the rules', Zhongan Wang [anhuinews,com]. Available at: Zhongan Jiankang [health.anhuinews.com], <http://health.big5.anhuinews.com/system/2004/04/05/001206076.shtml> (accessed 5 October 2010)

${ }^{27}$ 'The case of Zhang Xianzhu ended "Hepatitis B discrimination"', Renmin Fayuan Bao [People's Court Daily], 3 November 2006. Available at: Zhongguo Fayuan Wang [chinacourt.org], $<$ http://rmfyb.chinacourt.org/public/detail.php?id=102369> (accessed 6 October 2010).

${ }^{28}$ Ministry of Labor and Social Security, Opinions on the Protection of the Rights of People Having Hepatitis B Virus Antigen (18 May 2007).

${ }^{29}$ Article 30, Employment Promotion Law.

${ }^{30}$ In October 2010, for example, a draft open letter to the Central Government and the State Council urging further protection of the rights of HBV carriers was posted on HBV FORUM to solicit netizens' signature. The contents of this open letter and this signature campaign are available at: www.hbvhbv.name/qm/gq/QM.asp (accessed 10 October 2010).

31 'Prominent weiquan activist Lu Jun calls for unblocking "Gandan Xiangzhao Forum"', Radio Free Asia (Mandarin Channel), 4 July 2008. Available at: /www.rfa.org/mandarin/zhuanlan/shijimantan/lujun08062008165553.html (accessed 10 October 2010).

${ }^{32}$ Interview with Lu Jun, December 2009.

${ }^{33}$ Lincoln Dahlberg, 'The Internet and Democratic Discourse: Exploring the Prospects of Online Deliberative Forums Extending the Public Sphere', Information, Communication \& Society 4(4), December 2001: 615; Cass R. Sunstein, Republic.com 2.0, New Jersey: Princeton University Press, 2007; 
Zizi Papacharissi, 'The virtual sphere: The Internet as a public sphere', New Media \& Society 4(1), 2002: 9 .

${ }_{35}^{34}$ Stefan Wray, 'On Electronic Civil Disobedience', Peace Review 11(1), 1999:107, 109.

${ }^{35}$ Guobin Yang, 'Contention in Cyberspace', in Kevin J. O'Brien (ed.), Popular Protest in China, Cambridge, Mass.: Harvard University Press, 2008: 137-138.

${ }^{36}$ For an overview of the goals, functions and achievements of Yirenping, see 'An introduction to the Beijing Yirenping Centre'. Available at: Beijing Yirenping Centre, $<$ http://www.yirenping.org/article.asp? id $=35>$ (accessed 10 October 2010).

${ }^{37}$ Interview with staff members of Yirenping, January 2010.

${ }^{38}$ Ibid.

${ }^{39}$ Beijing Yirenping Centre, Jiuye Qishi Falü Weiquan Shouce - Yi 'Yigan Qishi' Weili, [Handbook on Rights Defending in Employment Discrimination - Using 'Hepatitis B Discrimination' as an Example], March 2010 (7th edition). Available at: www.yirenping.org/article.asp?id=339 (accessed 10 October 2010).

${ }^{40}$ See for example, Ziling, 'Reports of Mingpao and many other media on the Hepatitis B discrimination case in Hunan', Zhansheng Yigan [hbver.com], 26 July 2005. Available at: www.hbver.com/Article/ygqs/wqss/200507/4018.html (accessed 10 October 2010).

${ }^{41}$ Yang, supra note 9, p. 132.

${ }^{42}$ Interview with one staff member of Yirenping, December 2009.

${ }^{43}$ Interview with staff members of Yirenping, December 2009.

${ }^{44}$ Yirenping (ed) 工具包 [Tool Box], p. 2.

${ }^{45}$ Paragraph 2 of Article 33 of the Constitution of the People's Republic of China provides that: 'All citizens of the People's Republic of China are equal before the law.'

${ }^{46}$ The SPC's interpretation on the Qi Yuling case was made in 2001, but in a SPC decision in 2008, the SPC announced that this interpretation 'ceases to be applied'. Supreme People's Court, 'Reply on Whether an Infringement of a Citizen's Constitutional Right to Education By Means of Infringing His/Her Right to His/Her Name Should Bear Any Civil Responsibility (28 June 2001)'; Supreme People's Court, Decision on the Abolition of Judicial interpretations that were Issued before the end of 2007 (Seventh Batch) (24 December 2008).

${ }^{47}$ Marc Galanter, Why the "haves" come out ahead: speculations on the limits of legal

change. Law \& Society Review (1974) 9:95-160,

${ }^{48}$ Interview with staff members of Yirening, December 2009.

${ }^{49}$ Ibid.

${ }^{50} \mathrm{Ibid}$.

${ }^{51}$ Lin Xinghua, Chen Yu and Wang Changfeng, 'Is it worthwhile to initiate the "One Dollar and Twenty Cents" lawsuit', Jingji Ribao [Economic Daily], 30 January 1996, p. 1.

${ }^{52}$ Interview with staff members of Yirenping, December 2009.

${ }^{53}$ Ibid.

${ }^{54}$ Ibid

${ }^{55} \mathrm{Ibid}$.

${ }^{56}$ Ibid.

${ }^{57}$ Ibid.

${ }^{58}$ Supra note 44 above.

${ }^{59}$ Ibid.

${ }^{60}$ Ibid. The Shenzhen Intermediate People's Court allowed the appeal and awarded the appellant 3,000 RMB as damages.

${ }^{61}$ Interview with staff members of Yirenping, December 2009. Yirenping maintains mailing lists which include more than 1,000 lawyers and 2,000 reporters.

${ }^{62}$ Interview with staff members of Yirenping, December 2009.

${ }^{63}$ Ibid.

${ }^{64}$ Ibid.

${ }^{65}$ Long Zhouyuan, 'How difficult is environmental litigation?', Caixin Wang [caixin.cn], 17 February 2011. Available at: <http://video.caixin.cn/2011-02-17/100226323.html> (accessed 18 November 2011).

${ }^{66}$ Alex Wang, "Green litigation in China today" 18 July 2011 in ChinaDialogue 
http://www.chinadialogue.net/article/show/single/en/4413 (accessed 30 June 2012).

${ }^{67}$ For the details of this case, see for example, 'The facing of licence revocation by the two weiquan lawyers reflected the retrogression in the rule of law in China', Human Rights in China, 20 April 2010. Available at: <http://big5.hrichina.org/public/contents/press? revision\% 5 fid $=18683$ \&item\% $\%$ fid $=18597>$ (accessed 22 April 2010); 'The government's suppression of weiquan lawyers endangers the rule of law establishment in China', Human Rights in China, 22 April 2010. Available at: $<$ http://big5.hrichina.org/public/contents/press? revision\%5fid=19278\&item\%5fid=18685> (accessed 22 September 2010); and 'The Decision of Administrative Punishment of the Beijing Municipal Justice Bureau, No. 3 [2010]', available in the website of the Beijing Municipal Justice Bureau, $<$ http://www.bjsf.gov.cn/sy/sytztg/201005/t20100507_1279393.html > (accessed 27 September 2010).

${ }^{68}$ Luo Xiao, 'Tong Lihua: The Greatest Happiness is to Feel the Existence of Justice' Zhiye [Occupation] 13, 2007: 34; Sha Lei, 'Tong Lihua: Defender of the Weak', Zhongguanchun Magazine 10, 2008: 118.

${ }^{69}$ I thank Mr Zhou Dan (周丹) for raising this issue during our discussion in November 2011.

${ }^{70}$ Interview with staff members of Yirenping, December 2009.

${ }^{71}$ Elizabeth J Perry, 'Chinese Conceptions of "Rights": From Mencius to Mao - and Now', Perspectives on Politics 6, 2008: 45. 